AMOROUS ACTS 

F R A N C E S L R R S T U C C I A

\section{Amorous Acts}

Lacanian Ethics in Modernism, Film, and Queer Theory

STANFORD UNIVERSITY PRESS

STANFORD, CALIFORNIA 2006 
Stanford University Press

Stanford, California

(C) 2006 by the Board of Trustees of the Leland Stanford Junior University. All rights reserved.

No part of this book may be reproduced or transmitted in any form or by any means, electronic or mechanical, including photocopying and recording, or in any information storage or retrieval system without the prior written permission of Stanford University Press.

Library of Congress Cataloging-in-Publication Data

Restuccia, Frances L., date-

Amorous acts : Lacanian ethics in modernism, film, and queer theory / Frances L. Restuccia.

p. $\quad \mathrm{cm}$.

Includes bibliographical references and index. ISBN 0-8047-5182-X (cloth : alk. paper)

I. Lacan, Jacques, I90I-I98r. 2. Love.

3. Love in literature. 4. Love in motion pictures. 5. Queer theory. I. Title.

BFI 75.5.L68R $47 \quad 2006$

$809^{\prime} .933543-\mathrm{dc} 22 \quad 2006011303$

Typeset by BookMatters in 10/14 Janson 
To Kalpana 
